adw. dr Piotr Sobański LL.M. (Zielona Góra)

piotr.sobanski@adwokatura.pl

\title{
Warunkowe umorzenie postępowania karnego jako środek resocjalizacji sprawcy przestępstwa w orzecznictwie Sądu Najwyższego
}

\section{Uwagi wstępne} $2017 \mathrm{r}$

Niniejszy artykuł uwzględnia stan prawny, który obowiązuje na dzień 2 kwietnia

Zgodnie z art. $66 \S 1 \mathrm{KK}$ sąd może warunkowo umorzyć postępowanie karne, jeżeli wina i społeczna szkodliwość czynu nie są znaczne, okoliczności jego popełnienia nie budzą wątpliwości, a postawa sprawcy niekaranego za przestępstwo umyślne, jego właściwości i warunki osobiste oraz dotychczasowy sposób życia uzasadniają przypuszczenie, że pomimo umorzenia postępowania będzie przestrzegał porządku prawnego, w szczególności nie popełni przestępstwa ${ }^{1}$.

Warunkowe umorzenie postępowania powinno służyć jako środek resocjalizacji sprawcy przestępstwa, który ma wyeliminować krótkoterminowe kary pozbawienia wolności oraz kary nie związane z pozbawieniem wolności ${ }^{2}$. Zgodnie z katalogiem kar określonym w art. $32 \mathrm{KK}$, karami nieizolacyjnymi są grzywna (art. 32 pkt $1 \mathrm{KK}$ ) oraz ograniczenie wolności (art. 32 pkt $2 \mathrm{KK}$ ). Warunkowe umorzenie postępowania, nie będąc skazaniem, pozwala w określonych sytuacjach na zakończenie postępowania karnego z jednoczesnym uniknięciem wymierzenia kary sprawcy czynu zabronionego ${ }^{3}$. Instytucja warunkowego umorzenia postępowania karnego jest oryginalnym polskim środkiem poddania próbie sprawcy przestępstwa. Zastosowanie tego środka może mieć dodatni wpływ na przyszłą resocjalizację sprawcy, a taże zapobiec jego powrotowi do przestępstwa ${ }^{4}$.

\section{Materialnoprawne aspekty warunkowego umorzenia postępowania}

Zastosowanie instytucji warunkowego umorzenia postępowania jest możliwe tylko wtedy, gdy koniunkcyjnie występują okoliczności określone w art. 66 \& 1 KK. Ustawodawca dodatkowo wprowadził w art. 66 § 2 KK zakaz stosowania instytucji warunkowego umorzenia postępowania w odniesieniu do sprawców przestępstw zagrożonych karą przekraczającą 5 lat pozbawienia wolności. Okoliczności, o których mowa w art. $66 \mathrm{KK}$ mają w większości charakter materialnoprawny. Warunkują one uznanie niecelowości kontynuowania wszczętego postępowania karnego wobec sprawcy czynu zabronionego ${ }^{5}$.

Jak wynika z art. 66 § $1 \mathrm{KK}$ sąd może warunkowo umorzyć postępowanie karne w razie ustalenia, że wina i społeczna szkodliwość czynu nie są znaczne, a okoliczności

1 Ustawa z dnia 6 czerwca 1997 r. Kodeks karny, Dz. U. z 2016 r., poz. 1137 - tekst jednolity.

2 M. Jankowski, S. Momot, A. Ważny, Warunkowe umorzenie postępowania, Instytut Wymiaru Sprawiedliwości, Warszawa 2011, s. 2

3 P. Gensikowski, Instytucja przewidziana w art. 335 KPK a warunkowe umorzenie postępowania karnego, „Kwartalnik Krajowej Szkoły Sądownictwa i Prokuratury” 2014, Zeszyt 4, s. 6.

4 K. Juszka, Efektywność warunkowego umorzenia postępowania karnego w postępowaniu przygotowawczym i jurysdykcyjnym, „Ruch Prawniczy, Ekonomiczny i Socjologiczny” 2015, Zeszyt 4, s. 187.

5 Wyrok SN z dnia 17 maja 2016 r., III KK 28/16, Prok.i Pr.-wkł. 2016, nr 9, poz. 3. 
Warunkowe umorzenie postępowania karnego jako środek resocjalizacji...

popełnienia czynu nie budzą wątpliwości. Warunkowe umorzenie postępowania jest nierozerwalnie związane ze stwierdzeniem przez sąd winy ${ }^{6}$. Aby ustalić jednak winę, muszą być spełnione znamiona strony przedmiotowej czynu popełnionego przez oskarżonego. Zgodnie $\mathrm{z}$ art. 66 § 1 KK powinien zostać spełniony wymóg, aby okoliczności popełnienia czynu nie budziły wątpliwości Dotyczy to wypełnienia przez oskarżonego wszelkich znamion zarzucanego mu czynu, określonych w konkretnym przepisie, który zawiera opis zarzucanego przestępstwa ${ }^{7}$.

Sąd musi dojść po pierwsze do wniosku, że fakt popełnienia przestępstwa nie budzi wątpliwości, a zatem że istnieją wystarczające podstawy, aby oskarżonemu przypisać popełnienie tego czynu. Dodatkowo na sądzie spoczywa również obowiązek wyjaśnienia elementów przedmiotowych i podmiotowych przestępstwa ${ }^{8}$. Dla możliwości wydania orzeczenia w zakresie warunkowego umorzenia istotne jest zatem ustalenie wszelkich przesłanek odpowiedzialności karnej sprawcy. Warto przy tym zauważyć, że sąd może orzec o warunkowym umorzeniu postępowania, mimo że oskarżony nie przyznał się do popełnienia ${ }^{9}$. Uprzednie stwierdzenie winy sprawcy jest konieczne, aby następnie dokonać oceny czy jego wina jest znaczna, czy też nie jest znaczna ${ }^{10}$.

Poza przesłanką braku znaczności winy, przy warunkowym umorzeniu postępowania powinna zostać spełniona także przesłanka braku znaczności społecznej szkodliwości popełnionego przez sprawcę przestępstwa. Kwestia społecznej szkodliwości czynu ma bowiem kluczowe znaczenie w polskim procesie karnym. Zgodnie z art. 1 § 1 KK odpowiedzialności karnej podlega tylko ten, kto popełnia czyn zabroniony pod groźbą kary przez ustawę obowiązującą w czasie jego popełnienia. Jednak ustawodawca dodatkowo zastrzegł $w$ art. $1 \S 2 \mathrm{KK}$, że nie stanowi przestępstwa czyn zabroniony, którego społeczna szkodliwość jest znikoma. Przestępstwami są zatem wszystkie czyny zabronione, które noszą w sobie ładunek społecznej szkodliwości będący wyższym od znikomego.

Z art. 66 § $1 \mathrm{KK}$ wynika więc, że sąd może warunkowo umorzyć postępowanie karne, jeżeli został popełniony czyn zabroniony, spełniający wprawdzie przewidziany w art. $1 \S 2$ KK warunek karygodności, jednak gdy społeczna szkodliwość popełnionego przestępstwa nie jest znaczna. Przy ocenie stopnia szkodliwości społecznej czynu sąd zgodnie z treścią art. $115 \S 2 \mathrm{KK}$ bierze pod uwagę rodzaj i charakter naruszonego dobra, rozmiary wyrządzonej lub grożącej szkody, sposób i okoliczności popełnienia czynu, wagę naruszonych przez sprawcę obowiązków, jak również postać zamiaru, motywację sprawcy, rodzaj naruszonych reguł ostrożności i stopień ich naruszenia. Należy mieć na uwadze, że katalog okoliczności wymienionych w art. 115 § 2 KK ma charakter zamknięty. Ustawodawca pominął m.in. takie kryteria związane ze sprawcą, jak: wiek, opinia, właściwości i warunki osobiste ${ }^{11}$. Okoliczności te mają natomiast wpływ na ustalanie wysokości kary wobec sprawcy, co wynika z treści art. 53 § $2 \mathrm{KK}$, zawierającego zasady i dyrektywy wymiaru kary.

Należy podkreślić okoliczność, że zawarty w art. $66 \S 1 \mathrm{KK}$ warunek uprzedniej niekaralności sprawcy za przestępstwo umyślne ma bezwzględny charakter ${ }^{12}$. Ustalenie

\footnotetext{
6 Wyrok SN z dnia 9 stycznia 2002 r., III KKN 303/00, Prok.i Pr.-wkł. 2003, nr 2, poz. 3.

7 Wyrok SN z dnia 24 lutego 2005 r., V KK 435/04, Prok.i Pr.-wkł. 2006, nr 1, poz. 2.

8 Wyrok SN z dnia 20 października 2011 r., III KK 159/11, OSNKW 2012, z. 2, poz. 14.

9 Postanowienie SN z dnia 27 listopada 2003 r., V KK 301/03, OSNKW 2004, z. 1, poz. 9.

10 Wyrok SN z dnia 9 stycznia 2002 r., III KKN 303/00, Prok.i Pr.-wkł. 2003, nr 2, poz. 3.

11 Postanowienie SN z dnia 25 czerwca 2008 r., V KK 1/08, OSNKW 2008, z. 9, poz. 75.

12 Wyrok SN z dnia 4 października 2016 r., V KK 211/16, LEX nr 2123265; wyrok SN z dnia 6 listopada 2014 r., III KK 180/14, LEX nr 1548237.
} 
niekaralności jest niezbędne dla potrzeb rozważenia zastosowania warunkowego umorzenia postępowania. Sąd ma obowiązek dołożyć należytej staranności, aby poczynić jednoznaczne ustalenia w kwestii uprzedniej karalności oskarżonego ${ }^{13}$. Przesłanka niekaralności odnosi się do prawomocnych skazań, które nastąpiły do daty orzekania w przedmiocie warunkowego umorzenia postępowania ${ }^{14}$. Zastosowanie dobrodziejstwa warunkowego umorzenia wobec sprawcy ukaranego prawomocnym wyrokiem za przestępstwo umyślne w sposób rażący naruszyłoby przepis art. $66 \S 1 \mathrm{KK}$. Tym samym sąd podczas orzekania w przedmiocie warunkowego umorzenia musi dysponować aktualnymi informacjami o karalności oskarżonego, nadesłanymi z Krajowego Rejestru Karnego Ministerstwa Sprawiedliwości ${ }^{15}$. Warto również zauważyć, że nie tylko niekaralność sprawcy za przestępstwo umyślne, ale i wszelkie pozostałe określone w art. 66 KK przesłanki powinny bezwzględnie ziścić się w momencie stosowania przez sąd dobrodziejstwa warunkowego umorzenia postępowania wobec sprawcy czynu zabronionego ${ }^{16}$.

Ponadto należy podkreślić, że zgodnie z art. $66 \S 1$ KK sąd może warunkowo umorzyć postępowanie karne tylko wówczas, jeżeli istnieje uzasadnione przypuszczenie, że pomimo umorzenia postępowania sprawca będzie przestrzegał porządku prawnego, a w szczególności nie popełni przestępstwa ${ }^{17}$. Sąd ma zatem obowiązek sformułowania pozytywnej prognozy kryminologicznej wobec sprawcy czynu, aby mógł w danym postępowaniu skorzystać z instytucji unormowanej w art. 66-67 KK.

\section{Proceduralne aspekty zastosowania warunkowego umorzenia postępowania}

Zgodnie z art. $336 \S 1$ KPK w razie spełnienia przesłanek uzasadniających warunkowe umorzenie postępowania, prokurator może zamiast aktu oskarżenia sporządzić i skierować do sądu wniosek o warunkowe umorzenie ${ }^{18}$.

Jak wynika z treści art. $336 \S 2 \mathrm{KPK}$, do wniosku prokuratora stosuje się odpowiednio przepisy art. $332 \S 1$ pkt 1, 2, 4 i 5. Tym samym wniosek o warunkowe umorzenie postępowania powinien zawierać następujące elementy: imię i nazwisko oskarżonego, inne dane o jego osobie, dane o zastosowaniu środka zapobiegawczego oraz zabezpieczenia majątkowego; dokładne określenie zarzucanego oskarżonemu czynu ze wskazaniem czasu, miejsca, sposobu i okoliczności jego popełnienia oraz skutków, a zwłaszcza wysokości powstałej szkody; wskazanie przepisów ustawy karnej, pod które zarzucany czyn podpada oraz wskazanie sądu właściwego do rozpoznania sprawy. Uzasadnienie wniosku można natomiast ograniczyć do wskazania dowodów świadczących o tym, że wina oskarżonego nie budzi wątpliwości oraz do podania okoliczności przemawiających za postulowanym warunkowym umorzeniem (art. $336 \S 2$ zd. 2 KK). W oparciu art. $336 \S 3$ KPK prokurator może wskazać w skierowanym do sądu wniosku o warunkowe umorzenie postępowania karnego proponowany okres próby, obowiązki, które należy nałożyć na oskarżonego i, stosownie do okoliczności, wnioski co do dozoru, który sąd powinien zastosować w ocenie prokuratora w odniesieniu do sprawcy.

13 Wyrok SN z dnia 1 czerwca 2016 r., V KK 61/16, Prok.i Pr.-wkł. 2016, nr 9, poz. 2.

14 Wyrok SN z dnia 17 maja 2016 r., III KK 28/16, Prok.i Pr.-wkł. 2016, nr 9, poz. 3.

15 Wyrok SN z dnia 10 marca 2016 r., III KK 426/15; LEX nr 2005659.

16 Wyrok SN z dnia 17 maja 2016 r., III KK 28/16, Prok.i Pr.-wkł. 2016, nr 9, poz. 3.

17 Wyrok SN z dnia 20 października 2011 r., III KK 159/11, OSNKW 2012, z. 2, poz. 14.

18 Ustawa z dnia 6 czerwca 1997 r. Kodeks postępowania karnego, Dz. U. z 2016 r., poz. 1749 - tekst jednolity. 
Warunkowe umorzenie postępowania karnego jako środek resocjalizacji...

Jak wynika z art. $339 \S 1$ pkt 2 KPK, jeżeli zachodzi potrzeba rozważenia kwestii warunkowego umorzenia postępowania wobec osoby oskarżonej o popełnienie czynu zabronionego, prezes sądu kieruje sprawę na posiedzenie. Art. $336 \S 5 \mathrm{KPK}$ nakazuje, aby do wniosku o warunkowe umorzenie postępowania odpowiednio stosować przepisy dotyczące aktu oskarżenia. Zatem jeżeli zostanie wyznaczone posiedzenie w celu rozpoznania wniosku prokuratora o warunkowe umorzenie, to obowiązek odpowiedniego stosowania przepisów zawartych w Rozdziale 40 KPK skutkuje koniecznością zarządzenia przez prezesa sądu doręczenia oskarżonemu odpisu wniosku o warunkowe umorzenie (art. 338 § $1 \mathrm{KPK}$ ). Osarżonego należy pouczyć o prawie wniesienia pisemnej odpowiedzi na wniosek (art. $338 \S 2 \mathrm{KPK}$ ). Pouczenie to musi zawierać treść dotyczącą możliwości sprzeciwienia się oskarżonego warunkowemu umorzeniu, które wyłącza możliwość rozpoznania wniosku prokuratora na posiedzeniu i nakazuje skierowanie sprawy na rozprawę $^{19}$. Zgodnie z art. $341 \S 1 \mathrm{KPK}$ prokurator, oskarżony i pokrzywdzony mają prawo wziąć udział w posiedzeniu w przedmiocie warunkowego umorzenia postępowania. Udział ich jest jedynie obowiązkowy, jeżeli prezes sądu lub sąd tak zarządzi.

W art. 341 § 3 i 4 KPK została unormowana kwestia możliwości pojednania się między sprawcą a ofiarą przestępstwa. Jeżeli sąd uzna za celowe ze względu na możliwość porozumienia się oskarżonego z pokrzywdzonym w kwestii naprawienia szkody lub zadośćuczynienia, może odroczyć posiedzenie, wyznaczając stronom odpowiedni termin. Na wniosek oskarżonego i pokrzywdzonego, uzasadniony potrzebą dokonania uzgodnień, sąd zarządza stosowną przerwę lub odracza posiedzenie (art. $341 \S 3 \mathrm{KPK}$ ). Jak wynika $z$ art. $341 \S 4 \mathrm{KPK}$ sąd orzekając o warunkowym umorzeniu postępowania bierze pod uwagę wyniki porozumienia się oskarżonego z pokrzywdzonym.

Zgodnie $\mathrm{z}$ art. 341 \$ $5 \mathrm{KPK}$ w przedmiocie warunkowego umorzenia postępowania sąd orzeka na posiedzeniu wyrokiem. Należy podkreślić przy tym, że wyrok warunkowo umarzający postępowanie karne nie ma charakteru wyroku skazującego ${ }^{20}$. Warunkowe umorzenie nie jest ani formą, ani odmianą warunkowego skazania ${ }^{21}$. Przewidziana w art. $66 \mathrm{KK}$ instytucja jest natomiast warunkową rezygnacją $z$ ukarania sprawcy ${ }^{22}$. Z treści art. 66 i 67 KK wynika, że warunkowe umorzenie postępowania nie może zostać połączone z wymierzeniem sprawcy kary ${ }^{23}$.

Warunkowe umorzenie postępowania należy zaliczyć do środków związanych z poddaniem sprawcy próbie. Jak stanowi art. $67 \S 1 \mathrm{KK}$, warunkowe umorzenie następuje na okres próby, który wynosi od roku do 3 lat. Bieg okresu próby rozpoczyna się w chwili uprawomocnienia się wyroku warunkowo umarzającego postępowanie ${ }^{24}$. Sąd ma obowiązek określić w wydanym w trybie art. 341 § 5 KPK wyroku okres próby wobec sprawcy. Nie można tego uczynić w trybie art. $13 \S 1 \mathrm{KKW}$, który umożliwia zwrócenie się do sądu, który wydał orzeczenie, o rozstrzygnięcie wątpliwości co do jego wykonania. Z uwagi na ustawowy wymóg precyzyjnego określenia w wyroku rozstrzygnięcia co do czasu trwania próby, wykluczona jest możliwość precyzowania tego okresu dopiero w postępowaniu wykonawczym ${ }^{25}$.

Należy podkreślić, że sąd ma prawo, a nie obowiązek warunkowo umorzyć

19 Postanowienie SN z dnia 27 listopada 2003 r., V KK 301/03, OSNKW 2004, z. 1, poz. 9.

20 Wyrok SN z dnia 16 stycznia 2015 r., V KK 377/14, Prok.i Pr.-wkł. 2015, nr 5, poz. 4; wyrok SN z dnia 3 października 2008 r., III KK 167/08, Prok.i Pr.-wkł. 2009, nr 3, poz. 20.

21 Postanowienie SN z dnia 1 marca 2004 r., V KK 373/03, OSNwSK 2004, nr 1, poz. 437.

22 M. Jankowski, S. Momot, A. Ważny, op. cit., s. 6.

23 Wyrok SN z dnia 29 sierpnia 2012 r., II KK 199/12, LEX nr 1220795

24 Wyrok SN z dnia 14 stycznia 2014 r., IV KK 275/13, Prok.i Pr.-wkł. 2014, nr 4, poz. 5.

25 Wyrok SN z dnia 16 stycznia 2015 r., V KK 377/14, Prok.i Pr.-wkł. 2015, nr 5, poz. 4; wyrok SN z dnia 3 października 2008 r., III KK 167/08, Prok.i Pr.-wkł. 2009, nr 3, poz. 20. 
postępowanie, w wypadku łącznego spełnienia wszystkich przewidzianych w art. 66 KK przesłanek ${ }^{26}$.

W art. $67 \S 2$ i $3 \mathrm{KK}$ zostały unormowane obligatoryjne i fakultatywne obowiązki towarzyszące zastosowaniu instytucji warunkowego umorzenia. Umarzając warunkowo postępowanie karne, sąd może w okresie próby oddać sprawcę pod dozór kuratora lub osoby godnej zaufania, stowarzyszenia, instytucji albo organizacji społecznej, do której działalności należy troska o wychowanie, zapobieganie demoralizacji lub pomoc skazanym (art. 67 § $2 \mathrm{KK}$ ). Umarzając warunkowo postępowanie karne, sąd nakłada na sprawcę obowiązek naprawienia szkody w całości albo w części, a w miarę możliwości również obowiązek zadośćuczynienia za doznaną krzywdę, albo zamiast tych obowiązków orzeka nawiązkę (art. 67 § $3 \mathrm{KK}$ ).

Jak wynika z treści art. $67 \S 3 \mathrm{KK}$ w razie warunkowego umorzenia postępowania karnego, sąd obowiązany jest do nałożenia obowiązku naprawienia szkody wyłącznie wówczas, gdy powstanie szkody w zakresie dóbr pokrzywdzonego jest następstwem popełnionego przez sprawcę przestępstwa ${ }^{27}$. Obowiązek ten spoczywa na sądzie jedynie wówczas, gdy w czasie orzekania szkoda nadal istnieje ${ }^{28}$. Należy podkreślić, że unormowany w art. $67 \S 3 \mathrm{KK}$ obowiązek naprawienia szkody opiera się na tych samych zasadach co zobowiązanie cywilnoprawne. Tym samym wysokość określonego przez sąd w wyroku świadczenia nie może przewyższać wysokości tego zobowiązania ${ }^{29}$. Warto przy tym zauważyć, że nawiązka, niezależnie od funkcji odszkodowawczej, w sposób wychowawczy oddziałuje na sprawcę przestępstwa ${ }^{30}$.

W treści art. $67 \S 3 \mathrm{KK}$ zostały określone fakultatywne obowiązki, które sąd może nałożyć na sprawcę, gdy skorzysta z instytucji warunkowego umorzenia. Mowa tu świadczeniu pieniężnym wymienionym w art. 39 pkt $7 \mathrm{KK}$, zakazie prowadzenia pojazdów oraz o obowiązkach, które zostały wymienione w art. $72 \S 1$ pkt 1-3, 5-6b, 7a, 7b KK. Obowiązkami określonymi w art. $72 \S 1 \mathrm{KK}$, do których odsyła treść art. $67 \S 3 \mathrm{KK}$ są: informowanie sądu lub kuratora o przebiegu okresu próby, przeproszenie pokrzywdzonego, wykonywanie ciążącego na sprawcy obowiązku łożenia na utrzymanie innej osoby, powstrzymanie się od nadużywania alkoholu lub używania innych środków odurzających, poddanie się terapii uzależnień, poddanie się terapii, w szczególności psychoterapii lub psychoedukacji; uczestnictwo w oddziaływaniach korekcyjnoedukacyjnych; powstrzymanie się od kontaktowania się z pokrzywdzonym lub innymi osobami w określony sposób lub zbliżania się do pokrzywdzonego lub innych osób; opuszczenie lokalu zajmowanego wspólnie z pokrzywdzonym. Nałożenie tych obowiązków zależy od okoliczności sprawy, a w szczególności od charakteru popełnionego czynu. Są to obowiązki, które mogą zostać nałożone w określonych sytuacjach na sprawcę również przy jego skazaniu i zawieszeniu wykonania kary.

Warto zauważyć, że sąd orzekając w przedmiocie warunkowego umorzenia postępowania nie może zobowiązać oskarżonego do obowiązków, określonych w art. $72 \S$ 1 pkt 4, $7 \mathrm{KK}$, tj. do wykonywania pracy zarobkowej, do nauki lub przygotowania się do zawodu, powstrzymania się od przebywania w określonych środowiskach lub miejscach ani do przewidzianego w treści art. $72 \S 1$ pkt $8 \mathrm{KK}$ innego stosownego postępowania w

26 Wyrok SN z dnia 17 maja 2016 r., III KK 28/16, Prok.i Pr.-wkł. 2016, nr 9, poz. 3.

27 Wyrok SN z dnia 31 sierpnia 2007 r., V KK 228/07, Prok.i Pr.-wkł. 2008, nr 1, poz. 4.

28 Wyrok SN z dnia 31 sierpnia 2007 r., V KK 228/07, Prok.i Pr.-wkł. 2008, nr 1, poz. 4; wyrok SN z dnia 18 stycznia 2007 r., WK 30/06, OSNwSK 2007, nr 1, poz. 228.

29 Postanowienie SN z dnia 19 grudnia 2002 r., III KK 415/02, LEX nr 583863.

30 P. Gensikowski, Problematyka nawiązki jako środka towarzyszącego warunkowemu umorzeniu postępowania karnego, „Probacja” 2012, Nr 1, s. 133-146, s. 146. 
Warunkowe umorzenie postępowania karnego jako środek resocjalizacji...

okresie próby, które może zapobiec popełnieniu ponownie przestępstwa. Istotą środków probacyjnych, o których mowa w art. $72 \S 1 \mathrm{KK}$ jest jednak to, że mogą być wykonywane oraz egzekwowane wyłącznie w okresie próby ${ }^{31}$.

Wydanie na posiedzeniu wyznaczonym na podstawie art. $339 \S 1$ pkt $2 \mathrm{KPK}$, wyroku warunkowo umarzającego postępowanie jest dopuszczalne jedynie, gdy sąd ma podstawy do przyjęcia, że oskarżony nie sprzeciwia się zastosowaniu warunkowego umorzenia $^{32}$. Należy podkreślić, że do zastosowania warunkowego umorzenia postępowania nie jest konieczna zgoda sprawcy. Jak stanowi art. $341 \S 2 \mathrm{KPK}$, jeżeli oskarżony sprzeciwia się warunkowemu umorzeniu, jak również wtedy, gdy sąd uznaje, że warunkowe umorzenie byłoby nieuzasadnione, kieruje sprawę na rozprawę.

Wniosek prokuratora o warunkowe umorzenie postępowania zastępuje akt oskarżenia. Wówczas prokurator powinien jednak w terminie 7 dni dokonać czynności określonych w art. 333 § 1 i 2 KPK. Art. 333 KPK określa wymogi, które powinien spełniać wnoszony do sądu akt oskarżenia. powinien także zawierać. W akcie oskarżenia należy wprawdzie zamieścić listę osób, których wezwania oskarżyciel żąda, a także wykaz innych dowodów, których przeprowadzenia na rozprawie głównej domaga się oskarżyciel, jednak list i wykazów, o których mowa w art. 333 § $1 \mathrm{KPK}$, nie dołącza się do wniosku o warunkowe umorzenie postępowania ${ }^{33}$.

Skierowanie sprawy na rozprawę nie wyklucza zastosowania w wyniku rozprawy warunkowego umorzenia postępowania wobec oskarżonego, o ile w toku przewodu sądowego sąd ustali istnienie warunków przemawiających za zastosowaniem warunkowego umorzenia ${ }^{34}$. Zgodnie $\mathrm{z}$ art. $414 \S 1 \mathrm{KPK}$, w razie stwierdzenia po rozpoczęciu przewodu sądowego danych przemawiających za warunkowym umorzeniem postępowania, sąd wyrokiem umarza warunkowo postępowanie. Wydany na rozprawie wyrok warunkowo umarzający postępowanie karne podlega zaskarżeniu na zasadach ogólnych. Warto dodać, że sąd może również, mimo przyznania się oskarżonego uznać podczas posiedzenia, uznać że istnieją wątpliwości co do popełnienia zarzucanego czynu, i skierować sprawę na rozprawę ${ }^{35}$.

\section{Weryfikacja trafności prognozy kryminologicznej w okresie próby}

W trakcie okresu próby sprawdzana jest trafność prognozy kryminologicznej, stanowiącej jedną z przesłanek uprzedniego zastosowania warunkowego umorzenia postępowania ${ }^{36}$.

Przepis art. $67 \S 4 \mathrm{KPK}$ nakazuje odpowiednie stosowanie art. $74 \mathrm{KK}$. Istotne jest przede wszystkim odniesienie do art. $74 \S 2 \mathrm{KK}$, określającego kompetencje sądu podczas warunkowego zawieszenia wykonania orzeczonej kary i możliwości nakładania dodatkowych obowiązków na skazanego, o ile przemawiają za tym względy wychowawcze. Możliwość nakładania obowiązków również w okresie próby, na jaki umorzono warunkowo postępowanie, ma bowiem decydujące znaczenie dla resocjalizacji sprawcy. Zgodnie z art. $74 \S 2 \mathrm{KK}$ sąd może ustanawiać, rozszerzać lub zmieniać

31 Wyrok SN z dnia 10 grudnia 2008 r., II KK 106/08, OSNwSK 2008, nr 1, poz. 2530.

32 Postanowienie SN z dnia 27 listopada 2003 r., V KK 301/03, OSNKW 2004, z. 1, poz. 9.

33 T. Grzegorczyk, Kodeks postępowania karnego oraz ustawa o świadku koronnym, Wolters Kluwer, Warszawa 2008, s. 741.

34 Postanowienie SN z dnia 15 czerwca 2016 r., V KK 104/16, LEX nr 2080103; wyrok SN z dnia 4 października 2005 r., V KK 211/05, LEX nr 157210.

35 Postanowienie SN z dnia 27 listopada 2003 r., V KK 301/03, OSNKW 2004, z. 1, poz. 9.

36 Wyrok SN z dnia 14 stycznia 2014 r., IV KK 275/13, Prok.i Pr.-wkł. 2014, nr 4, poz. 5. 
obowiązki wymienione w art. $72 \S 1 \mathrm{KK}$ albo od wykonania nałożonych obowiązków zwolnić sprawcę czynu.

W sytuacjach, w których resocjalizacja sprawcy w okresie próby nie przebiega pomyślnie zastosowanie mają unormowania zawarte w art. $68 \mathrm{KK} . \mathrm{W}$ art. 68 § 1 i $2 a \mathrm{KK}$ unormowane zostały obligatoryjne przesłanki podjęcia warunkowo umorzonego postępowania Zgodnie $\mathrm{z}$ art. $68 \S 1 \mathrm{KK}$ sąd podejmuje postępowanie karne, jeżeli sprawca w okresie próby popełnił przestępstwo umyślne, za które został prawomocnie skazany. Sąd podejmuje także postępowanie karne, jeżeli sprawca w okresie próby rażąco narusza porządek prawny, mimo udzielenia pisemnego upomnienia przez sądowego kuratora zawodowego, chyba że przemawiają przeciwko temu szczególne względy (art. 68 § 2a $\mathrm{KK})$.

W art. 68 § 2 i $3 \mathrm{KK}$ zostały określone fakultatywne przesłanki podjęcia warunkowo umorzonego postępowania. Zgodnie z art. $68 \S 2 \mathrm{KK}$ sąd może podjąć postępowanie karne, jeżeli sprawca w okresie próby rażąco narusza porządek prawny, w szczególności gdy popełnił inne niż określone w art. 68 § $1 \mathrm{KK}$ przestępstwo, jeżeli uchyla się od dozoru, wykonania nałożonego obowiązku lub orzeczonego środka karnego, środka kompensacyjnego lub przepadku albo nie wykonuje zawartej z pokrzywdzonym ugody. Sąd może także podjąć postępowanie karne, jeżeli sprawca po wydaniu orzeczenia o warunkowym umorzeniu postępowania, lecz przed jego uprawomocnieniem się, rażąco narusza porządek prawny, a w szczególności gdy w tym czasie popełnił przestępstwo (art. $68 \S 3 \mathrm{KK})$.

Należy mieć na uwadze, że zgodnie z art. 68 § $4 \mathrm{KK}$ warunkowo umorzonego postępowania nie można podjąć później niż w ciągu 6 miesięcy od zakończenia określonego w treści wyroku okresu próby.

Jak wynika z art. $551 \mathrm{KPK}$ w razie podjęcia postępowania warunkowo umorzonego sprawa toczy się od nowa na zasadach ogólnych przed sądem właściwym do jej rozpoznania. Warto dodać, że w takiej sytuacji brak jest przeszkód, aby po podjęciu postępowania sąd ponownie umorzył je warunkowo. Sąd może to uczynić zarówno na posiedzeniu, jak i na rozprawie głównej. Możliwość ponownego warunkowego umorzenia istnieje także na etapie postępowania odwoławczego. Aby sąd mógł wówczas ponownie umorzyć warunkowo postępowanie, muszą zaistnieć jednak w chwili orzekania okoliczności, o których mowa w art. $66 \mathrm{KK}$.

\section{Uwagi końcowe}

Efektywność warunkowego umorzenia zależy od pomyślnego zakończenia okresu próby, braku powrotu do przestępstwa, utrwalenia właściwej postawy społecznej sprawcy oraz przestrzegania porządku prawnego ${ }^{37}$.

Należy przy tym zauważyć, że określony w art. $66 \S 2$ KK zakaz stosowania warunkowego umorzenia postępowania w przypadku popełnienia czynów zagrożonych karą przekraczającą 5 lat pozbawienia wolności obowiązuje od dnia 1 lipca 2015 r. Zmiana przepisu umożliwiła sądom stosowanie warunkowego umorzenia wobec szerszego kręgu sprawców przestępstw. Poprzednia regulacja umożliwiała stosowanie warunkowe umorzenia do sprawców czynów karalnych zagrożonych karą nie przekraczającą 5 lat pozbawienia wolności jedynie w ściśle określonych sytuacjach. Było to możliwe jedynie w wypadku, gdy pokrzywdzony pojednał się ze sprawcą, sprawca naprawił szkodę lub pokrzywdzony i sprawca uzgodnili sposób naprawienia szkody. Zasadą było bowiem

37 K. Juszka, op. cit., s. 188. 
Warunkowe umorzenie postępowania karnego jako środek resocjalizacji...

stosowanie warunkowego umorzenia do sprawców przestępstw zagrożonych karą nie przekraczającą 3 lat pozbawienia wolności. Górna granica ustawowego zagrożenia wymagana dla warunkowego umorzenia uniemożliwiała tym samym stosowanie tej instytucji przy czynach zagrożonych karą przekraczającą 3 lata pozbawienia wolności, tzw. przestępstwach bez ofiar, a zatem nie dokonanych z pokrzywdzeniem konkretnego podmiotu. W omawianym aspekcie należy wskazać, że ustawową definicję pokrzywdzonego zawiera art. 49 KPK.

Zmiany dokonane przez ustawodawcę $\mathrm{w}$ art. $66 \mathrm{KK}$ polegające na rozszerzeniu możliwości stosowania instytucji warunkowego umorzenia postępowania powinny przyczynić się docelowo do zwiększenia liczby warunkowych umorzeń w ogólnej liczbie rozsztrygnięć w postępowaniach karnych wobec sprawców, którzy nie byli uprzednio karani za przestępstwo umyślne. Ustawodawca dostrzegł bowiem dodatni aspekt resocjalizacyjny związany ze stosowaniem dobrodziejstwa warunkowych umorzeń postępowań.

\section{Streszczenie:}

Artykuł omawia aspekty prawne warunkowego umorzenia postępowania karnego jako środka mogącego przyczynić się do pełnej resocjalizacji sprawcy czynu zabronionego, który nie był karany uprzednio za przestępstwa umyślne. Artykuł uwzględnia orzecznictwo Sądu Najwyższego odnoszące się do stosowania instytucji warunkowego umorzenia postępowania.

Słowa kluczowe:

warunkowe umorzenie postępowania karnego, środki probacyjne, resocjalizacja

\section{Abstract:}

\section{Conditional discontinuance of criminal proceedings as a resocialization measure} of perpetrator of a criminal offence in the Supreme Court's judicial practice

The paper presents the legal aspects of conditional discontinuance of criminal proceedings as the measure which can resocialize the perpetrator of a criminal offence who has not been previously sentenced for an intentional offence. The paper respects judicial practice of the Supreme Court which refers to the conditional discontinuance of proceedings.

\section{Key words:}

conditional discontinuance of criminal proceedings, probation measures, resocialization

\section{Bibliografia:}

Gensikowski P., Instytucja przewidziana w art. 335 KPK a warunkowe umorzenie postępowania karnego, „Kwartalnik Krajowej Szkoły Sądownictwa i Prokuratury” 2014, Zeszyt 4, s. 5-13.

"Gensikowski P., Problematyka nawiązki jako środka towarzyszącego warunkowemu umorzeniu postępowania karnego, „Probacja” 2012, Nr 1, s. 133-146.

Grzegorczyk T., Kodeks postępowania karnego oraz ustawa o świadku koronnym, Wolters Kluwer, Warszawa 2008

Jankowski M., Momot S., Ważny A., Warunkowe umorzenie postępowania, Instytut Wymiaru Sprawiedliwości, Warszawa 2011.

Juszka K., Efektywność warunkowego umorzenia postępowania karnego w postępowaniu przygotowawczym i jurysdykcyjnym, „Ruch Prawniczy, Ekonomiczny i Socjologiczny” 2015, Zeszyt 4, s. 187196. 